\title{
Perdagangan Perempuan Nepal ke India dan Peran Jejaring Feminis Transnasional
}

\author{
Fatma Yusuf Eko Suwarno \\ Program Studi Hubungan Internasional, Universitas Indonesia, Jawa Barat - Indonesia \\ Email: ftmaysf96@gmail.com \\ Submitted: 17 Agustus 2020| Accepted: 28 Desember 2020
}

\begin{abstract}
Nepal has faced high rates of woman trafficking to India for a long time. Various efforts were made but the rate did not decrease. This article intended to examine this phenomenon by examining the transnational feminist network (TFN), such as The Global Alliance Against Women Trafficking (GAAWT). GAAWT focuses on changes in the political, economic, social, legal system and structures related to the practice of trafficking in women by using a human rights approach to people who are regulated, non-discriminatory, uphold equality and uphold the principles of accountability, participation, and inclusiveness in the methodology, organizational structure and procedures. This study utilizes qualitative methods and transnational feminism theoretical framework. The result shows that GAAW'T TFN has played a role in overcoming the issue of trafficking of Nepalese women to India by voicing the human rights of women in Nepal with a human rights approach. Even so, the trafficking of Nepalese women to India is still high. Therefore, evaluating approaches that pay attention to cultural aspects as well as various political identities at play can increase the effectiveness of TFN.
\end{abstract}

Keywords: GAAWT, Trafficking, Feminist, Transnational, Network.

\begin{abstract}
Abstrak
Nepal sudah cukup lama menghadapi tingginya tingkat perdagangan perempuan ke India. Berbagai upaya dikerahkan namun tidak menunjukkan angka penurunan. Tulisan ini bertujuan untuk mengkaji fenomena tersebut dengan menelaah peran jejaring feminis (transnational feminist network), seperti. Global Alliance Against Women Trafficking (GAATW). GAATW berfokus pada perubahan di ranah politik, ekonomi, sosial, sistem legal, dan struktur yang berkaitan dengan praktik perdagangan perempuan dengan mnggunakan pendekatan Hak Asasi Manusia orang-orang yang diperdagangkan, bersifat non-diskriminatoris, menjunjung kesetaraan, serta menjunjung prinsipprinsip akuntabilitas, partisipasi, dan inklusivitas di dalam metodologi, struktur organisasi, dan prosedurnya. Kajian ini menggunakan metode kualitatif dan kerangka teori feminisme transnasional. Hasilnya menunjukkan bahwa GGAATW sebagai TFN sudah berperan dalam menanggulangi isu perdagangan perempuan Nepal ke India dengan menyuarakan hak asasi perempuan di Nepal dengan pendekatan HAM. Walaupun begitu, perdagangan perempuan Nepal ke India masih menunjukkan angka yang tinggi. Oleh karena itu, evaluasi pendekatan yang memperhatikan aspek kultural serta beragam identitas politik yang bermain dapat meningkatkan efektivitas TFN.
\end{abstract}

Kata kunci: GAATW, Perdagangan, Feminis, Jaringan, Transnasional.

\section{PENDAHULUAN}

Topik perdagangan manusia merupakan isu yang kontroversialhal tersebut merupakan suatu hal yang kompleks, multidimensional, dan membutuhkan berbagai macam perspektif dalam mengkajinya. Ia pun 
bukan sesuatu yang mudah untuk diselesaikan dan masih banyak terjadi di kehidupan nyata. Kekerasan terhadap perempuan (Violence Against Women) sendiri juga bukan lagi isu yang asing untuk didengar, ia merupakan isu yang menyebar ke berbagai lapisan masyarakat di dunia—salah satunya adalah perdagangan perempuan. Di dalam perdagangan manusia sendiri, perempuan mendominasi $80 \%$ dari jumlah aktivitas perdagangan manusia dalam skala global (Trafficking Report, 2017). Nepal dalam hal ini merupakan salah satu negara di dunia dengan permasalahan perdagangan manusia yang serius. Horizons The Asia Foundation (2001) menyebutkan bahwa masalah perdagangan manusia di Nepal sudah mencapai titik yang akut. Mayoritas kasus pun dipenuhi oleh kekerasan seksual, di mana perempuan dijadikan komoditas seksual dalam bentuk prostitusi paksa, pornografi, pernikahan paksa, dll. (Sarkar, 2011a).

Selanjutnya, dalam membahas permasalahan perdagangan perempuan di Nepal, perlu juga untuk meninjau dimensi dari perdagangan perempuan serta peningkatannya. Dimensi perdagangan manusia di Nepal terbagi menjadi tiga, pertama adalah perdagangan manusia internal atau domestik, perdagangan manusia antar negara, dan perdagangan manusia dari Nepal ke India. Secara internal, perdagangan perempuan di Nepal merupakan isu yang masih rawan terjadi. Selain itu, perdagangan perempuan di Nepal juga mengalami peningkatan. Data dari NHRC (National Human Rights Commission) Nepal (2018) menuliskan bahwa kasus perdagangan perempuan yang tercatat meningkat dari 185 menjadi 305 dari catatan periode 2013-2018. Perdagangan ke luar negeri juga masih banyak terjadi. Contohnya adalah ke Saudi Arabia, China, Malaysia, dll. di mana mayoritas korban adalah perempuan (NHRC, 2018b). Walaupun begitu, jumlah perdagangan perempuan lintas batas yang terjadi dari Nepal ke India merupakan yang tertinggi diantara perdagangan internal dan perdagangan ke negara lain. Dalam hal ini, ia mengalami peningkatan yang signifikan. Jika dibandingkan dengan jumlah kasus perdagangan perempuan di Nepal yang mencapai 305 kasus, jumlah perdagangan dari Nepal ke India meningkat dari 72 kasus menjadi 607 dari catatan periode 2012-2017, setara dengan 500\% (NHRC, 2018c) — sejalan dengan hal tersebut, jumlah perempuan yang diperdagangkan dari Nepal ke India (tercatat dari jumlah kasus yang ditangani oleh kedutaan) terdiri dari 69\% perempuan jika dibandingkan dengan $10 \%$ di Saudi Arabia. Perbatasan Nepal dan India juga terkenal dengan perdagangan 
perempuan yang juga terdiri dari remaja perempuan—di mana jalur perdagangan tersebut merupakan salah satu yang tersibuk di dunia. Diperkirakan bahwa setiap tahunnya, sekitar 5000 sampai 10.000 perempuan Nepal diperdagangkan antara Nepal dan India (Banshkota, 2004).

Melihat tingginya tingkat perdagangan manusia dari Nepal ke India khususnya perdagangan perempuan dari pemaparan diatas, tidak menunjukkan bahwa pemerintah Nepal tidak tinggal diam dalam melakukan tindakan untuk menanggulangi isu tersebut. Subedi (2009) memaparkan upaya-upaya pemerintah Nepal dalam melawan permasalahan perdagangan perempuan yang termanifestasi melalui kerangka hukum, kebijakan negara dan mekanisme institusi, dan program khusus perempuan. Kemudian, pemerintah Nepal bersama dengan Kementrian Perdamaian dan Rekonstruksi, NGO internasional, dll. mencanangkan National Action Plan, yaitu program masif yang mengerahkan banyak lapisan masyarakat dan organisasi untuk mengentas permasalahan perdagangan perempuan Nepal dari tahun 20112016 (Peace Women, n.d.). Namun, upaya pemerintah dalam hal ini dilihat belum menghasilkan hasil yang begitu signifikan dalam mengatasi permasalahan perdagangan perempuan. Sebaliknya, perdagangan perempuan di Nepal (berdimensi internal maupun lintas batas dengan India), seperti yang sudah dipaparkan diatas, mengalami peningkatan dari rentang waktu program National Action Plan ini dijalankan.

Tabel 1 Langkah anti-perdagangan orang di Nepal, 2012 - 2016

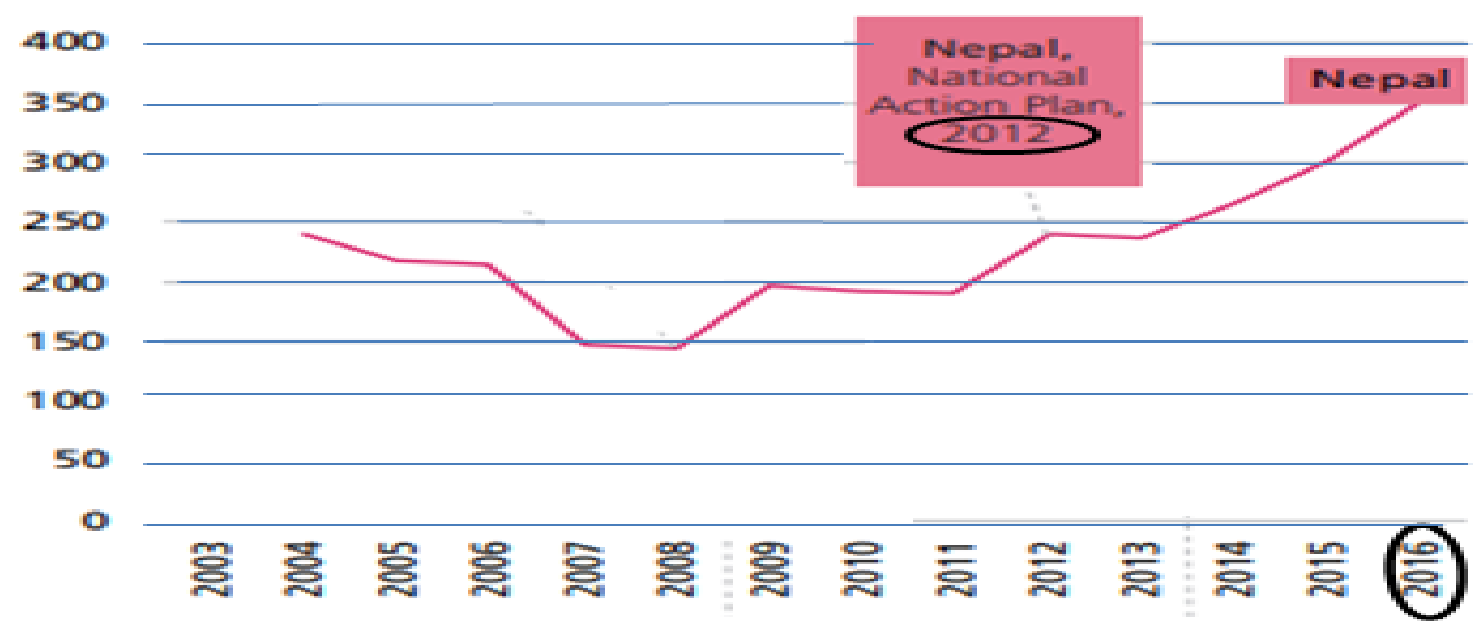

Sumber: The Global Report on Trafficking In Persons (2018). 
Permasalahan perdagangan perempuan merupakan satu dari sekian yang banyak dibahas oleh feminis. Feminisme dalam hal ini merupakan suatu wujud perlawanan dari beragam jenis penindasan serta eksploitasi terhadap perempuan dengan pengalamannya yang beragam (Kempadoo, 2001). Walaupun begitu, berbagai hambatan masih menyelimuti gerakan pembebasan perempuan. Seiring berjalannya waktu, peran jejaring dan solidaritas feminis kemudian banyak diupayakan untuk menciptakan suatu tatanan dalam menentang hegemoni patriarki-yaitu membangun wadah bagi perempuan lintas batas negara (dalam konteks transnasional) untuk berorganisasi atau berjejaring sebagai upaya untuk melebarkan peran serta partisipasi perempuan dalam mengentas problematika ketidaksetaraan dan penindasan terhadap perempuan, salah satunya adalah praktik perdagangan perempuan.

Berdasarkan latar belakang tersebut, pertanyaan penelitian yang hendak diulas di dalam tulisan ini adalah bagaimana peran jaringan feminis transnasional dalam mengatasi peningkatan perdagangan perempuan dari Nepal ke India tahun 2012-2016)?. Pertanyaan ini dijawab dengan mengambil Global Alliance Against Trafficking in Women (GAATW) sebagai salah satu contoh jejaring feminis yang berada pada tingkat global dan regional serta mengidentifikasi dan menganalisis program perjuangan yang mereka bangun, serta hambatan yang dihadapi. GAATW melihat bahwa hubungan patriarki yang termanifestasikan dalam globalisasi ekonomi neoliberal memiliki tanggung jawab terhadap tingkat keseriusan perdagangan perempuan. Ia juga melihat bahwa untuk membawa perubahan yang signifikan, dibutuhkan keterlibatan perempuan sebagai aktor feminis di berbagai tingkat dalam upaya advokasi yang dilakukan.

\section{TINJAUAN PUSTAKA}

\section{Perdagangan Perempuan di Nepal}

Pembahasan perdagangan perempuan di Nepal dalam hal ini penting untuk melihat sisi kekerasan yang muncul dari dalam negeri serta kaitannya dengan perdagangan perempuan yang melibatkan lintas batas (yaitu dari Nepal ke India). Hal ini juga penting untuk melihat sejauh mana penelitian mengenai perdagangan perempuan di Nepal sudah dibahas. Tulisan pertama berjudul 'Cheli-Beti' Discourses of Trafficking and Constructions of Gender, Citizenship and Nation in Modern Nepal yang ditulis oleh Sushma Joshi di mana tulisan tersebut berfokus menjelaskan mengenai proses diskursus yang diperankan oleh media dalam menyebarkan nilai-nilai bias gender 
dalam menggambarkan korban perdagangan perempuan. Media disini dilihat memiliki peran dalam merepresentasikan dan mengkonstruksikan gambaran mengenai perempuan di Nepal—yang seharusnya digambarkan sebagai kelompok yang beragam dan multifaset.

Selanjutnya, tulisan yang akan dibahas berjudul ' $W$ e are looked down upon and rejected socially': a qualitative study on the experiences of trafficking survivors in Nepal yang ditulis oleh Pranab Dahal, Sunil Kumar Joshi \& Katarina Swahnberg. Tulisan tersebut berfokus dalam narasi korban perdagangan perempuan Nepal yang tidak mendapatkan bantuan secara sosial, budaya, dan politik ketika mereka keluar dari lingkaran perdagangan manusia tersebut. Kebijakan yang melindungi hak-hak korban perdagangan perempuan juga dinilai sebagai tidak efisien dan komprehensif dalam melindungi kesejahteraan korban.

Dapat dilihat dari tulisan-tulisan diatas bahwa mereka sama-sama menempatkan korban perempuan sebagai fokus dari penelitian mereka di mana kesejahteraan mereka diperhatikan dilihat dari berbagai faktor. Hal ini dapat menjadi masukan bagi penulis dalam melihat kekerasan yang terjadi di Nepal.

\section{Perdagangan Perempuan dari Nepal ke India}

Setelah meninjau ulasan mengenai kompleksitas perdagangan perempuan di Nepal (yang berguna untuk menelaah pentingnya menempatkan perempuan dari berbagai faktor dan dimensi), hal yang tidak kalah penting adalah meninjau berbagai pendekatan dalam menelaah kasus perdagangan perempuan dari Nepal ke India. Dalam tulisannya yang berjudul Cross-Border Trafficking in Nepal and India-Violating Women's Rights, Tameshnie Deane menggunakan pendekatan HAM (Hak Asasi Manusia) dalam melihat problematika perdagangan perempuan dari Nepal ke India. Penelitian ini kemudian melihat bahwa lemahnya hukum domestik dan penyelenggaraannya menjadi faktor yang menjelaskan keberlangsungan dari perdagangan perempuan dari Nepal ke India.

Tulisan selanjutnya adalah Trafficking in Girls and Women in Nepal for Commercial Sexual Exploitation: Emerging Concerns and Gaps yang ditulis oleh Govind Subedi di mana penyebab perdagangan perempuan di Nepal (mencakup perdagangan perempuan dari Nepal ke India) dianalisis dari struktur ekonomi sosial, norma-norma sosial dan perilakunya, serta lemahnya sistem hukum dan kurangnya komitmen politik, kurangnya pengetahuan mengenai perdagangan 
manusia, dan kurangnya edukasi untuk perempuan di Nepal.

Tulisan selanjutnya berjudul Trafficking of Women and Girls for Sex Trade from Nepal to India yang ditulis oleh Siddhartha Sarkar. Tulisan tersebut melihat bahwa tingginya tingkat perdagangan perempuan dan eksploitasi seks dilihat dari perspektif kebijakan dan hukum pemerintah India. Penulis melihat bahwa perlu penanggulangan yang serius dari pihak India-yaitu melalui pelatihan khusus untuk penyelenggara-penyelenggara hukum dalam perannya untuk menutup praktik prostitusi ilegal, melindungi korban perdagangan manusia, dan menginvestigasi pelakupelaku kejahatan.

\section{Gerakan Feminis dalam \\ Mengatasi Isu Kekerasan Perempuan}

Setelah meninjau berbagai tulisan yang membahas mengenai kompleksitas serta dimensi perdagangan perempuan Nepal ke India, hal yang kemudian penting untuk dibahas adalah bagaimana gerakan feminis berperan dalam mengatasi isu kekerasan perempuan di Nepal. Gerakan feminis merupakan suatu hal yang berhubungan dengan kuasa, kontestasi gender dan patriarki-di mana ia berhubungan dengan proses globalisasi yang mengaburkan batasan-batasan geografis. Dalam tulisannya yang berjudul Feminist Movements from Global to Local: Has it helped Women Empowerment Process? Patriarchy and Status of Nepali Women yang ditulis oleh Prabin K. Prajapati, ia menjelaskan bagaimana gerakan feminis memberikan pengaruh terhadap isu ketidakadilan gender di Nepal—serta hubungannya dengan kebebasan mobilitas dan ekonomi. Tulisan tersebut menekankan betapa pentingnya untuk Nepal untuk mengerahkan proses empowerment yang masif terutama dalam sosialisasi pengetahuan gender. Institusi feminis dan gerakan feminis dilihat sebagai pemegang peran dalam menanggulangi isu kekerasan perempuan-namun ia membutuhkan koordinasi yang lebih komprehensif dan memusat terkait nilai dan tujuannya.

Tulisan selanjutnya berjudul Peran Jejaring Feminis Asia Pacific Forum on Women, Law, and Development (APWLD) dalam Merepresentasikan Hak Asasi Perempuan yang ditulis oleh Lathiefah Widuri Retyaningtyas. Dalam tulisannya, ia menekankan mengenai pentingnya jejaring feminis dalam menanggulangi permasalahan hegemoni patriarki yang merugikan perempuan seperti kekerasan seksual, pernikahan di bawah umur, serta hubungan eksploitatif lainnya-dan terutama dalam merepresentasikan Hak Asasi Perempuan. Penulis melihat 
bahwa APWLD selaku aktor jejaring feminis memiliki pengaruh dan peran yang signifikan dalam mengatasi isuisu HAM yang terjadi di negara-negara Asia Pasifik.

Dari semua tulisan-tulisan diatas, dapat dilihat bahwa kajian yang mendalami dan mengevaluasi permasalahan perdagangan perempuan dari Nepal ke India dalam kerangka jejaring feminis masih sangat kurang. Beberapa tulisan mengenai problematika tersebut dan pengaruh gender hanya menyentuh permukaannya saja—seperti pengaruh norma sosial dan diskriminasi gender di Nepal. Oleh karena itu, penulis berharap dapat mengisi celah penelitian dengan membahas permasalahan perdagangan perempuan dari Nepal ke India dari tinjauan kerangka jejaring feminisme transnasional.

\section{METODE PENELITIAN}

Metode penelitian yang akan digunakan dalam jurnal ini adalah metode penelitian kualitatif, dimana ia memiliki pendekatan induktif yang berasal dari data-data yang telah dikumpulkan. Neuman (2000) melihat bahwa metode kualitatif dapat diambil melalui kalimat, kata, simbol, dan lain sebagainya. Bryman (2004) juga menjelaskan bahwa pengumpulan data dapat melalui wawancara, partisipasi, literatur dan lain lain. Jenis penelitian ini bersifat eksplanatif dimana penjelasan yang ditulis berusaha memaparkan fenomena yang terjadi dan mencari serta memahami sebab akibat dari munculnya permasalahan tersebut.

Kemudian, tahap-tahap yang akan dilakukan dalam penelitian kualitatif yang dijelaskan oleh Bryman (2004) dimulai dengan menentukan rumusan masalah, melakukan pemilihan subjek penelitian yang sesuai, kemudian melakukan pengumpulan data yang dilanjutkan dengan melakukan interpretasi data. Selanjutnya, proses yang dilakukan adalah menemukan teori yang sesuai untuk menjawab rumusan masalah dan juga disatukan dengan menggunakan interpretasi data yang telah dimiliki.

Untuk menjawab rumusan masalah dalam tulisan ini, penulis akan mencari dan menggali data-data utama yang akan membantu, yaitu mengenai sejarah kekerasan perempuan di Nepal dan India, dan kedudukan perempuan di Nepal dan India. Data-data yang telah didapatkan tersebut akan dianalisa oleh penulis untuk menjawab rumusan masalah penelitian.

\section{KERANGKA PEMIKIRAN}

Dalam meninjau jejaring feminis GAATW, hal yang perlu diperhatikan juga adalah pemahaman mengenai feminisme transnasional dalam melihat praktik perdagangan perempuan. 
Feminisme transnasional merupakan suatu respons dari gerakan solidaritas aktivis feminis kontemporer (Inderpal \& Caren, 1994). Ia melihat bagaimana globalisasi dan kapitalisme mempengaruhi perempuan lintas negara, ras, gender, kelas, dan seksualitas. Paradigma feminis transnasional tersebut dipengaruhi oleh teori feminisme poskolonialisme yang menekankan bagaima legitimasi kolonisasi membentuk opresi sosial, ekonomi, dan politik yang mempengaruhi perempuan secara global (Inderpal \& Caren, 1994). Praktik aktivisme feminis transnasional bersolidaritas secara lintas batas untuk memahami peran negara, ras, kelas, gender, dan seksualitas dalam mengkritik dan menggugat struktur kuasa patriarki dan kapitalisme. Feminisme transnasional dalam hal ini memperhatikan bahwa bentuk-bentuk praktik perdagangan perempuan kurang dapat sepenuhnya ditinjau di dalam kurungan narasi bahwa perempuan adalah korban; tapi juga memperhatikan konteks sosial, ekonomi global, dan sejarah serta ketimpangan relasi kuasa yang membentuk narasi dominan dan opresif dari pengalaman perempuan di dalam aktivitas perdagangan itu sendiri. Teori feminisme transnasional menyarankan untuk memikirkan kembali strategi dan program praktis untuk mengatasi situasi khusus bagi perempuan kulit berwarna dalam perdagangan seks global (dengan pengalamannya yang beragam) serta membangun aliansi global.

Untuk meninjau permasalahan perdagangan perempuan lintas batas dari Nepal ke India, kerangka gerakan aliansi transnasional menjadi suatu hal yang tidak kalah penting untuk ditelaah. Moghadam (2000) menekankan bahwa organisasi transnasional yang menjunjung nilai feminisme berusaha menyelesaikan isu-isu kebijakan sosial, ekonomi, serta kebijakan luar negeri secara supranasional. Berkaitan dengan hal tersebut, ia melihat adanya kesamaan pola dari gerakan perempuan terutama dalam pemberdayaan perempuan dan advokasi keadilan gender; bagaimana ia mengikutsertakan negara dan institusi antar pemerintah. TFN (Transnational Feminist Network) menurutnya merupakan bentuk jaringan solidaritas sosial yang emansipatoris, terkolektif, dan berkelanjutan. Strategi yang digunakan oleh TFN adalah memobilisasi tekanan-tekanan terhadap serangan dan institusi yang berusaha mengusik status perempuan.

Mogadham (2005) memaparkan pola serupa yang terdapat di dalam gerakan transnasional pada umumnya adalah pertama, bergabung dengan jaringan global serta mengaktifkan perjuangan mereka untuk keadilan 
gender (yaitu memobilisasi tekanan melawan kekuatan luar). Kedua, TFN juga digambarkan melakukan tindakan seperti melancarkan agitasi di daerah perbatasan serta lintas negara-bangsa demi membangun kesadaran masyarakat dan partisipasinya. Dalam hal ini, mereka bekerja sama mengutas kebijakan sosial mengenai kemanusiaan, pembangunan, dan isu militerisasi dengan berbagai macam pihak seperti media, kelompok HAM, tenaga kerja, dsb. Ketiga, jaringan TFN saling terhubung satu sama lain dan ia mencakup wilayah lokal, nasional, regional, dan transnasional. Keempat, jaringan TFN juga berpartisipasi di tingkat multilateral dan antar pemerintah.

\section{Global Alliance Against Trafficking of Women (GAATW)}

Global Alliance Against Trafficking of Women (GAATW) didirikan di Chiang Mai, Thailand pada tahun 1994 dan berkembang menjadi sebuah organisasi global. Hal ini bertujuan untuk mempromosikan penghormatan terhadap hak asasi manusia dari orang-orang yang telah menjadi korban perdagangan manusia, termasuk mereka yang terkena perbudakan paksa, kerja paksa, atau praktik-praktik yang mirip perbudakan (GGATW, n.d.). Kebebasan mendasar para korban ini sering ditolak melalui paksaan, penipuan, atau ikatan hutang yang diterapkan oleh para pelaku perdagangan manusia. Karena perdagangan perempuan secara tidak proporsional berdampak pada perempuan dan anak perempuan, GAATW memberikan perhatian khusus pada kebutuhan para korban perempuan. Sejauh ini, mereka telah menerbitkan informasi termasuk buku pegangan bagi perempuan untuk memberdayakan dan membantu mereka dari eksploitasi perdagangan manusia. Hal ini memperkuat salah satu prinsip GAATW bahwa orangorang yang diperdagangkan tidak harus diperlakukan sebagai korban, melainkan harus dibantu menuju pemberdayaan mereka sendiri (GGATW, n.d.). GAATW juga bekerja untuk meningkatkan kondisi kehidupan dan pekerjaan di negaranegara asal orang-orang yang diperdagangkan, serta untuk menyediakan alternatif ekonomi yang layak. Ia juga bergerak aktif dalam mendefinisikan kembali instrumeninstrumen anti-perdagangan internasional dengan menguraikan standar-standar hak asasi manusia untuk perawatan orang-orang yang diperdagangkan (GGATW, n.d.).

GAATW menerapkan pendekatan hak asasi manusia untuk perdagangan manusia, yang terdiri dari: Memusatkan hak asasi manusia dari orang-orang yang diperdagangkan dan mereka yang berada dalam situasi 
rentan, dalam semua kegiatan antiperdagangan; Mengakui kesetaraan semua orang untuk menggunakan, membela, dan mempromosikan hak asasi manusia yang melekat, universal, dan tak terpisahkan serta nondiskriminatif terhadap keturunan etnis, usia, orientasi atau preferensi seksual, agama, jenis kelamin, usia, kebangsaan dan pekerjaan (termasuk pekerjaan di sektor informal seperti pekerjaan rumah tangga, pekerjaan seks, dll.); Mengedepankan prinsip akuntabilitas, partisipasi dan inklusivitas atau nondiskriminatif dalam metodologi kerja, dan struktur dan prosedur organisasi. Dalam hal ini, perwakilan dari organisasi mereka yang terkena dampak langsung oleh perdagangan sangat didorong dan didukung (GGATW, n.d.). Kemudian, kerangka kerja GAATW merujuk dari website GGATW disusun berdasarkan tiga arah tematik strategis utama yaitu:

Pertama, yaitu akuntabilitas. Ia bertujuan untuk meningkatkan akuntabilitas semua pemangku kepentingan anti-perdagangan yang terlibat dalam desain atau implementasi tanggapan antiperdagangan, terhadap orang-orang yang hak asasinya ingin mereka lindungi.

Kedua, akses ke keadilan, yang bertujuan untuk memperluas ruang bagi orang-orang yang diperdagangkan dan pekerja migran untuk mempraktikkan hak asasi mereka dengan meningkatkan akses ke keadilan dan memerangi semua bentuk diskriminasi yang berdampak pada kemampuan perempuan untuk menggunakan hak asasi mereka ketika mereka berhubungan dengan perdagangan manusia.

Ketiga, kekuasaan dalam migrasi dan pekerjaan, yang memusatkan analisis kekuatan perempuan dalam pekerjaan dan migrasi mereka untuk menilai dengan lebih baik dampak migrasi dan kebijakan perburuhan terhadap perempuan, dan untuk bekerja menuju proses perburuhan dan migrasi yang mencerminkan kebutuhan, aspirasi dan kemampuan migran.

Keempat, GAATW juga melayani anggotanya melalui advokasi internasional, penelitian dan komunikasi strategis serta media. Ia juga menghasilkan sejumlah publikasi ilmiah yang menantang dan meningkatkan pemahaman tentang perdagangan manusia.

\section{Perdagangan Perempuan Nepal ke India dan Peran GAATW}

Perdagangan perempuan Nepal ke India merupakan fenomena yang cukup rumit dan multidimensional. Secara historis, perdagangan perempuan Nepal sudah terjadi sejak tahun 1846 di periode rezim otokrat keluarga Rana, dan berlanjut hingga 
periode monarki absolut, yaitu rezim panchayat (1960-1989) sampai sekarang (Subedi, 2009). Praktik-praktik kekerasan sosiokultural yang patriarkis juga banyak menimpa perempuan Nepal di dalam sejarah (dan juga suku etnik yang masih memegang nilai-nilai tradisional). Salah satunya adalah Badi. Badi pada awalnya adalah kasta hiburan yang terdiri dari penyanyi, penari dan musisi. Seiring berjalannya waktu, perubahan politik, budaya dan ekonomi kemudian berkontribusi dan menghasilkan pengembangan serta praktik prostitusi tersebut sebagai strategi bertahan hidup bagi banyak orang di komunitas Badi. Dikatakan juga bahwa prostitusi adalah "pekerjaan kasta tradisional" dari Badi dan sering didefinisikan sebagai bagian dari sistem kasta (CEDAW, n.d.). Budaya patriarki di Nepal juga tercerminkan dalam komunitas yang menormalisasikan pengiriman perempuan untuk diperdagangan. Aktivis perdamaian feminis berpendapat bahwa "penindas" perempuan terdapat di antara keluarga dekat atau pasangan, dan teror terhadap perempuan merupakan teror yang tersamar dan meluar, yang terjadi di rumah (Summer dalam Priatin, 2007). Hal ini membuat perempuan semakin rentan terhadap ancaman perdagangan perempuan dan eksploitasi seksual, di mana orangorang terdekat mereka dapat menjerumuskan mereka ke dalam lingkaran perdagangan manusia. Contohnya adalah suku Tamang yang merupakan $70 \%$ dari populasi Nepal di mana ayah, saudara laki-laki, atau pacar adalah yang mengirim perempuan untuk diperdagangkan di India. Oleh karena itu, dapat dilihat bahwa perdagangan perempuan ini merupakan isu yang masih rentan dihadapi oleh perempuan Nepal sendiri. Perempuan di Nepal dalam hal ini kerap kali diperdagangkan untuk eksploitasi seksual, eksploitasi buruh, dan kegiatan ilegal lainnya dengan mayoritas kasus dipenuhi oleh kekerasan seksual, yaitu perempuan dijadikan komoditas seksual dalam bentuk prostitusi paksa, pornografi, pernikahan paksa, dll. (Sarkar, 2011a).

Hal ini ditambah dengan praktik perdagangan melalui migrasi ilegal, di mana ia bekerja melalui jejaring sosial antara Nepal dan India. Dalam hal ini, perdagangan perempuan terjadi melalui banyak rute, di mana sebagian besar terjadi dalam jaringan pedagang dari desa atau tempat kerja ke perbatasan, dan perbatasan ke tujuan, dan terjadi untuk eksploitasi seksual, eksploitasi tenaga kerja, dan kegiatan ilegal lainnya (Sarkar, 2011a). Perpindahan orang-orang dari Nepal ke India cukup mudah mengingat perbatasan yang panjang dengan India. Terdapat empat belas titik masuk yang legal, tetapi gerakan lintas batas ilegal 
tanpa dokumen sering dilakukan sejak India memiliki kebijakan perbatasan terbuka dengan Nepal. Dalam hal ini, pemerintah Nepal secara aktif mendukung migrasi tenaga kerja lintasperbatasan dengan mengakui aliran remitansi yang signifikan ke Nepal, tetapi pada saat yang bersamaan (Subedi, 2009), aliran tenaga murah ini dieksploitasi oleh para pedagang manusia yang menangkap perempuan dan anak-anak yang paling rentan untuk perdagangan seks. Hal ini menunjukkan bahwa partisipasi dalam migrasi desa-kota meningkatkan risiko diperdagangkan. Mereka dikirim dari daerah pedesaan untuk bekerja di kotakota seperti yang diatur oleh seorang perekrut, atau mereka dengan antusias bermigrasi untuk mencari pekerjaan yang lebih baik, terpikat oleh janji cinta, hiburan, dan dengan harapan perbaikan kondisi ekonomi.

Selain dimensi sejarah, sistem adat, dan ekonomi seperti yang dijelaskan diatas-NGO dan donor melakukan beberapa penelitian tentang tren perdagangan perempuan di Asia Selatan seperti Nepal dan menyoroti bagaimana kemiskinan, migrasi, agama, pekerjaan, jenis kelamin, kekuasaan, uang dan kekerasan saling terkait erat (Poudel \& Smyth, 2002 dalam Richardson et al., 2009).

Argumen dalam tulisan ini kemudian dibangun dengan menempatkan GAATW dalam kerangka TFNs untuk meninjau seberapa matang jejaring solidaritas feminis regional Asia Pasifik dalam menangani permasalahan perdagangan perempuan dari Nepal ke India. GAATW dilihat sebagai jejaring feminis dengan kerangka kerja yang cukup komprehensif-bahasannya dalam meninjau permasalahan perdagangan perempuan menyentuh ranah ekonomi, politik, hukum, kebijakan, serta faktor sosial (GGATW, n.d.). Ia menjalankan strateginya dengan menyatukan perjuangan perempuan dengan latar belakang permasalahan yang beragam ke dalam satu wadah - ia menghargai perbedaan dimensi serta konteks perdagangan perempuan itu sendiri dan bersolidaritas sebagai perlawanan kolektif untuk mengkontestasikan hegemoni patriarki. Strategi TFNs seperti yang digambarkan Mogadham tergambarkan di dalam programprogram yang dijalankan di dalam kerangka kerja GAATW. Ia turut melakukan mobilisasi perlawanan terhadap perdagangan perempuan dengan berkolaborasi bersama gerakan-gerakan sosial lainnya seperti masyarakat, media, gerakan HAM, dsb. Kemudian, ia juga mendorong perempuan untuk berpartisipasi dari akarnya hingga lintas batas negara. GAATW tidak lepas dalam hubungan dengan mitra lokal anggota- 
anggotanya di mana teknologi dan informasi adalah bagian yang tidak kalah penting untuk berjejaring dan bersolidaritas. Selain melakukan penelitian mengenai diskusi perdagangan perempuan tiap tahunnya, media massa juga menjadi bagian yang penting dari GAATW dalam mengedukasi persepsi publik mengenai migran dan merepresentasikan perempuan di luar konsepsi-konsepsi seperti korban, teraniaya, dll (GGATW Annual Report, 2016). Media dilihat untuk memiliki kontribusi nyata dalam menyebarluaskan gagasan tersebut dan menggambarkan pengalaman perempuan yang beragam. Contohnya adalah pemberitaan media online GGATW yang menggambarkan aktivitas organisasi Shakti Shamuha. Dapat dilihat bahwa korban perdagangan perempuan tidak digambarkan dengan representasi yang stereotipikal tentang korban pada umumnya.

Fokus utama dalam kerangka kerja GAATW adalah bagaimana perempuan menggunakan feminisme sebagai pisau analisis untuk membedah dimensi-dimensi aktivitas migrasi di mana komponen feminis diutamakan untuk dimasukkan dalam praktik migrasi yang aman, pengembangan kemampuan, hak pekerja perempuan, dan literasi finansial. Salah satunya adalah, di tahun 2013, ia memfokuskan untuk mengembangkan modul pelatihan yang menguatkan kapasitas aktor tingkat lokal yang berhubungan dengan perempuan di level komunitas (GGATW Annual Report, 2013). Projek tersebut juga menekankan signifikansi dari pengalaman perempuan untuk menganalisa dan memproses situasi yang berhubungan. Strategi empowerment dalam mengorganisasikan perempuan merupakan hal yang penting ditekankan. Kemudian, bersama dengan Alliance Against Trafficking in Women in Nepal (AATWIN), jaringan nasional di Nepal, mereka mengoordinasikan administrasi alat penilaian GAATW dan konsultan independen yang terlatih dalam metodologi penelitian untuk memfasilitasi workshop analisis data. Salah satu hasil perkembangan yang terlihat adalah di Sindhupalchok, di mana tim peneliti dan NGO yang berpartisipasi berkoordinasi dengan CDO dan Sekretaris Komite Pengembangan Desa dan berhasil membentuk kelompok kerja untuk mengkoordinasikan kegiatan antiperdagangan manusia di 15 desa di wilayah tersebut (GGATW Annual Report, 2013). Walaupun begitu, hambatan atau tantangan dalam proses tersebut juga tidak luput di dalam laporan tahunannya—salah satunya adalah permasalahan teknis, 
profesionalitas (dalam memproses data), dan dukungan finansial.

Kemudian, proyek-proyek lain di dalam GAATW (bersama dengan ILO) membahas mengenai sosialisasi informasi kepada perempuan mengenai safe migration di Nepal, India, dan Bangladesh di tahun 2015-untuk memberikan pengetahuan mengenai kondisi negara yang dituju dan menyediakan program pengembangan skill di komunitas masing-masing di fase pre-migrasi (GGATW Annual Report, 2015). Tidak kalah penting adalah asistensi terhadap perempuan yang mengalami tindakan kekerasan melalui workshop DMT (Dance Movement Therapy) yang memasukkan teknik psycho-physical untuk kemudian dapat diaplikasikan di dalam kehidupan sehari-hari (GGATW Annual Report, 2015). Hal ini menunjukkan kepedulian terhadap situasi perempuan di Nepal dalam menghadapi kondisi tersebut.

GAATW juga tidak mengabaikan peran kebijakan serta hukum sebagai alat untuk menegakkan terjaminnya hak asasi perempuan. Salah satunya adalah di tahun 2012, bersama dengan OHCHR (Office of the High Commissioner for Human Rights), GGATW mengadakan konsultasi ahli berjudul Human Rights at International Borders: Exploring Gaps in Policy and Practice di mana ia meninjau kebijakan perbatasan mengenai hak asasi manusia di perbatasan serta berkontribusi dalam memberikan concept paper (GGATW Annual Report, 2012). Pertemuan tersebut juga merekomendasikan pembentukan inisiatif strategis untuk pemangku kepentingan dalam kaitannya dengan hak asasi manusia di perbatasan internasional, termasuk strategi litigasi strategis di tingkat nasional, regional dan internasional, strategi advokasi luas yang akan mempengaruhi wacana politik tentang migrasi dan mendorong respons terhadap migrasi tidak teratur berdasarkan tanggung jawab bersama dan norma-norma hak asasi manusia, strategi solidaritas dan kemitraan dengan para pemangku kepentingan utama; termasuk negara asal dan transit, serta sektor swasta seperti media dan komunitas bisnis. Dalam menyajikan perspektif alternatif yang memihak perempuan, GAATW juga cukup aktif di berbagai forum-forum antar pemerintah-mengajukan proposal, aplikasi, serta dokumen lain untuk pertimbangan terhadap kondisi perempuan dalam konteks perdagangan manusia. Pada tahun 2014, GAATW mengambil bagian dalam peninjauan 20-tahun antarpemerintah Asia-Pasifik mengenai the Beijing Platform for Action (BPfA), yang menjadi kerangka kerja yang mereka anggap paling komprehensif tentang kesetaraan gender (GGATW Annual Report, 2014). 
Permasalahan perdagangan perempuan merupakan suatu hal yang mutifaset dan ia berhubungan dengan banyak dimensi-salah satunya adalah masyarakat yang patriarkis. Penyelesaiannya pun membutuhkan pendekatan yang beragam, tidak hanya dengan kerangka kebijakan saja; namun juga melihatnya dengan perspektif dasar mengenai ketimpangan relasi kuasa posisi perempuan. Walaupun tantangan dalam menyelesaikan hal tersebut tidak mudah, upaya yang dilakukan GAATW untuk memperjuangkan hak asasi perempuan sebagai salah satu upaya untuk menanggulangi isu perdagangan perempuan merupakan suatu hal yang patut untuk diapresiasi. Kendati demikian, data yang ditunjukkan oleh NHRC Nepal menunjukkan tren perdagangan perempuan yang meningkat, walaupun berbagai upaya banyak diusahakan oleh GAATW. Hal yang tidak kalah penting untuk diulas adalah permasalahan akses antar perbatasan. Masyarakat Nepal sendiri memiliki akses bebas untuk memasuki India, dan karenanya, perdagangan perempuan menjadi sulit untuk diidentifikasi (Sarkar 2014b). Keakuratan data pun menjadi kendala dikarenakan hal tersebut. Hal ini juga ditambah dengan stigma sosial mengenai perdagangan perempuan dikarenakan mayoritas akan eksploitasi seksual yang memperunyam proses pengumpulan data statistik untuk upaya penanggulangan yang lebih efektif (Subedi, 2009). Dapat dikatakan bahwa data-data mengenai jumlah korban perdagangan perempuan bisa lebih tinggi dari yang sudah dilaporkan. $\mathrm{Hal}$ ini menunjukkan tingkat kompleksitas yang tinggi dalam melihat peningkatan perdagangan perempuan Nepal ke India.

Dalam meninjau teori kerangka TFN, Mogadham (2005) memandang jaringan feminis transnasional sebagai jaringan yang tidak begitu hierarkis, serta lebih berorientasi pada penciptaan koalisi yang melintasi perbatasan, dan lebih sadar secara politis tentang batas-batas kontekstual pengetahuan mereka. Walaupun begitu, penulis berpendapat bahwa penting juga untuk mengulas dimensi identitas politik yang saling berinteraksi seperti kelas, ras, dan etnis. Mohanty (2013) menjelaskan pentingnya dimensi dekolonisasi keilmuan serta teori feminis yang menentang pandangan ilmiah yang tidak berasal dari komunitas perempuan yang tersubordinasi di dunia Selatan dan Utara, lalu sebagai gantinya, menyerukan perhatian pada kekhasan sejarah dan budaya dalam memahami agensi kompleks mereka sebagai subyek yang dipelajari. Oleh karena itu, aspek kultural yang lebih spesifik dari kerangka kerja GAATW 
dapat lebih ditonjolkan untuk meninjau masalah perdagangan perempuan di masing-masing negara-dalam konteks ini adalah perdagangan perempuan dari Nepal ke India (dengan keberagaman aspek patriarkis yang tertanam di sana).

\section{KESIMPULAN}

Perdagangan perempuan merupakan permasalahan kompleks yang membutuhkan berbagai macam pendekatan. Walaupun begitu, jejaring feminis memiliki peran yang penting dalam memperjuangkan hak asasi perempuan dalam menghadapi hegemoni patriarki untuk kesejahteraan serta kesetaraan dalam konteks perdagangan perempuan. GAATW dalam hal ini cukup berperan dalam menyuarakan hak asasi perempuan di Nepal dengan pendekatan HAM yang menggunakan strategi akuntabilitas, akses kepada keadilan, kekuasaan dan migrasi, serta advokasi komunikasi. Hal ini dapat dilihat dari analisis kerangka kerja GGATW yang ditinjau dari laporan tahunan tahun 2012 sampai 2016 yang melibatkan advokasi HAM lewat media, upaya akuntabilitas kebijakan dan hukum, rehabilitasi korban, dan lain sebagainya. Namun, perannya dilihat kurang menunjang penurunan angka perdagangan perempuan dari Nepal ke India. Tidak dapat diabaikan juga bahwa faktor-faktor seperti ekonomi, geografis, budaya patriarki, dan lain sebagainya. dilihat memiliki pengaruh dalam menjelaskan tingginya tingkat perdagangan perempuan. Oleh karena itu, akan lebih baik jika penyelesaiannya pun juga meliputi dimensi-dimensi yang beragam—salah satunya adalah meninjau kompleksitas budaya. Dalam hal ini, diperlukan masyarakat beserta individu-individu untuk turut serta menjadi bagian dari perubahan pola pikir, sikap, dan keyakinan sehingga dapat menciptakan lingkungan yang sehat bagi perempuan di mana pun mereka berada.

\section{REFERENSI}

CEDAW Nepal. (2011) Shadow Report on the 4th \& 5 th Periodic Report by The Government of Nepal on CEDAW. Tersedia di: https://www.ecoi.net/en/file/local/1 152605/1930_1314007608_fwldnepalcedaw49.pdf (Diakses: 22 Juni 2020).

Dahal, P., Joshi, S.K., \& Swahnberg, K. (2015) "We are looked down upon and rejected socially': a qualitative study on the experiences of trafficking survivors in Nepal", Global Health Action, (8)1, DOI: 10.3402/gha.v8.29267 (Diakses: 24 Juli 2020).

Deane, T. (2010) "Cross-Border Trafficking in Nepal and India_-Violating Women's Rights”, vol. 11, pp. 491 513. Doi: https://doi.org/10.1007/s12142-0100162-y (Diakses: 27 Juli 2020).

GAATW. (2012) Annual Report 2012. Tersedia di: https://gaatw.org/GAATW\%20R eports/2012_GAATW_Annual_Repo 
rt \%20_webversion.pdf (Diakses: 22

Juni 2020).

GAATW. (2013) Annual Report 2013.

Tersedia

di: https://www.gaatw.org/GAATW \%20Reports/2013_Annual_Report.pd

f (Diakses: 22 Juni 2020).

GAATW. (2014) Annual Report 2014..

Tersedia di:

https://www.gaatw.org/about-

us/annual-reports (Diakses: 22 Juni

2020).

GAATW. (2015) Annual Report 2015.

Tersedia di:

https://gaatw.org/GAATW\%20Repo rts/2015_GAATW_Annual_Report.p df (Diakses: 22 Juni 2020).

GAATW. (2016) Annual Report

2016.. Tersedia di:

https://gaatw.org/GAATW\%20Repo rts/2016_GAATW_Annual_Report.p df (Diakses: 22 Juni 2020).

GGATW. (n.d.) Basic Principles of GGATW (Online). Tersedia di: https://www.gaatw.org/aboutus/basic-principles (Diakses: 27 Juli 2020).

GGATW. (n.d.) Global Alliance Against Women Trafficking History (Online) Available at: https://www.gaatw.org/aboutus/history (Diakses: 19 Desember 2020).

Grewal, I., \& Kaplan, C. (1994) Scattered Hegemonies: Postmodernity and Transnational Feminist Practices. Minneapolis: University of Minnesota Press.

Horizons The Asia Foundation. (2001) Prevention of Trafficking and the Care and Support of Trafficked Persons In the Context of an Emerging

HIV/ AIDSEpidemic in Nepal (Online). Tersedia di: https://asiafoundation.org/resources /pdfs/NepalTrafficking.pdf (Diakses: 16 Juli 2020).
Joshi, S. (2001) “Cheli-Beti' Discourses of Trafficking and Constructions of Gender, Citizenship and Nation in Modern Nepal", South Asia: Journal of South Asian Studies, (24)1, pp. 157-175, DOI: $10.1080 / 00856400108723442$ (Diakses: 24 Juli 2020).

Kempadoo, K. (2001) Women of Color and the Global Sex Trade: Transnational Feminist Perspectives. York University.

Mogadham, V. M. (2000) Transnational Feminist Networks, Collectuve Action in an Era of Globalization. International Sociology. SAGE.

Moghadam, V. M. (2005) Globalizing Women: Transnational Feminist Networks. John Hopkins University Press.

Mohanty, C. T. (2013) “Transnational Feminist Crossings: On Neoliberalism and Radical Critique", Journal of Women in Culture and Society, (38)4, pp. 967 991. Tersedia di: https://doi.org/10.1086/669576 (Diakses: 22 Juli 2020).

NHRC. (2018) Trafficking In Persons In Nepal. Lalitapur: National Human Rights Commission.

Prajapati, P. (2008) Feminist Movements from Global to Local: Has it helped Women Empowerment Process? Patriarchy and Status of Nepali Women. Nepal Research.

Retyaningtyas, W. (2018) "Peran Jejaring Feminis Asia Pacific Forum on Women, Law, and Development (APWLD) dalam Merepresentasikan Hak Asasi Perempuan" Jurnal Hubungan Internasional, (11)1, pp. 73 - 90.

Sarkar, S. (2016) "Trafficking of Women and Girls for Sex Trade from Nepal to India. Challenge", (59)5, pp. 434-458. DOI: 10.1080/05775132.2016.1226090 (Diakses: 24 Juli 2020).

Trafficking Report. (2007) US Department of State Trafficking in Persons Report (Online). Tersedia di: https://2009- 
2017.state.gov/j/tip/rls/tiprpt/2007/ index.htm (Diakses: 27 Juli 2020).
United Nations Office on Drugs and Crime (UNODC). (2018) The Global Report on Trafficking in Persons. New York: United Nations. 